Status Report

\title{
Petroleum Exploration in India - A perspective and Endeavours
}

\author{
AJAY KUMAR DWIVEDI* \\ Director (Exploration), Oil and Natural Gas Corporation Ltd, Jeevan Bharathi Building, New Delhi, \\ India
}

(Received on 15 May 2016; Accepted on 25 June 2016)

\begin{abstract}
Indian oil industry has come a long way since the first oil discovery at Digboi in 1889 through concerted exploratory efforts. Production of oil from a 5 barrels per day level from a single field in Assam has grown to more than 750000 barrels per day from over 50 major oil and gas in seven sedimentary Basins and is projected to attain 1 million barrels per day mark in near future. After Independence, oil and gas exploration was accorded high priority and was taken up by National, Private and International oil companies across the 26 sedimentary Basins covering an area of about 3.14 million sq. kms. Of the 26 sedimentary Basins, 7 Basins are producing oil and gas today. Sedimentary Basins of India are categorised into four categories based on their degree of hydrocarbon prospectivity as presently known. At present India's estimated hydrocarbon resource is of the order of 28 billion tonnes of oil equivalent (BTOE) and an Initial In-place volume of about 11.18 billion tonnes of oil equivalent (BTOE). A project for re-assessment of the resource potential of Indian Sedimentary Basins has been initiated by Government of India with active participation of ONGC, OIL and DGH in view of extensive availability of new data from all the Sedimentary Basins.

Currentefforts are to enhance the production from category-I Basins with a focus on upgrading the Category-II Basins to Category-I Basins. Present paper outlines the endeavours during last few years through opening up of new areas, especially frontier areas of Proterozoic Basins of Vindhyan and Satpura, Deep offshore Basins of Bay of Bengal and Arabian Sea within Indian exclusive economic zone, Andaman fore-arc and back-arc Basins, unconventional sources of hydrocarbons such as Basement exploration, CBM (Coal Bed Methane), shale oil and gas, gas hydrates and leveraging the technology advances in Petroleum exploration.
\end{abstract}

Keywords: Petroleum; Resources; Reserves; Category; Basins; NELP; Frontiers; Unconventional

\section{Introduction}

Quest for Petroleum in India spans over 162 years since the first lease given in Assam by British government during 1854. A new chapter and challenging journey of Indian upstream Petroleum industry began with discovery of oil from the historic first well Digboi No:1 in 1889 barely 30 years after the first Drake Oil well was drilled by Col. E L Drake in Northwest Pennsylvania, USA. Indian upstream industry since then has travelled a long way through various socio-political changes and surged ahead with the economic growth of the country. Growth of Indian economy and the development of the upstream industry have always moved hand in hand. Sustained efforts by the Indian upstream industry have resulted

\footnotetext{
*Authorfor Correspondence: E-mail: dir_exp@ongc.co.in
}

in discovery of more than 830 oil and gas fields including 50 major fields with an increase in production from an insignificant 5 bopd from a single field in Assam to present production of 750000 bopd across the country. Independent India witnessed an enhanced exploratory activity in its sedimentary Basins by the then newly created National Oil Companies leading to opening up of new Petroliferous Basins of Cambay, Rajasthan, Assam \& Assam-Arakan fold Belt, the prolific Western Offshore, Krishna-Godavri and Cauvery Basins. The spectacular achievements by these NOC's have brought India into the World Oil Map. Sustained exploratory efforts by National Oil companies coupled with the initiatives by GOI in terms of New Exploration License Policy (NELP) has opened up the industry for exploration by International 
Oil and gas companies, as well as Private oil companies. As on date the Indian E\&P industry is operated by over 117 companies consisting of 11 PSU's, 58 Indian Private Companies and 48 International/Foreign Oil and Gas Companies targeted to explore the 26 sedimentary Basins covering an area of 3.14 million square kilometres, including the deep water areas beyond $400 \mathrm{~m}$ bathymetry.

Exploratory efforts by these companies resulted in accreting about 11187 MMTOE of in place hydrocarbon volume by 2015 , an increase of $32 \%$ as compared to base year of 2006 .

India's demand for fossil fuel by 2040 is estimated to grow by CAAGR (Compounded Annual Average Growth Rate) of 3.6\% for oil and $4.6 \%$ for natural gas to keep pace with the projected economic growth. The oil import dependency of the India is predicted to rise to $90 \%$ from the current $70 \%$. To meet the increasing energy demand Government of India has adopted several policies such as opening up of upstream exploration through competitive bidding under NELP during 1997-98, marginal field policy during 2015 and is now moving towards Open Acreage Policy model for future acreages under Hydrocarbon Exploration Licence Policy (HELP).

An overview of the status of exploration in the petroliferousBasins of India, their future perspective and the endeavours carried out by Indian E\&P companies, especially Indian NOC's leveraging the advances in the technology for establishing producible hydrocarbons has been presented in the following paragraphs.

\section{Sedimentary Basins of India}

Exploratory efforts since 1850's by foreign private oil companies (Assam Railways and Trading Company Limited (AR\&T), Assam Oil Company (AOC) and Burma Oil Company (BOC) and later by NOC's from late 50's and subsequently by private/foreign companies (1980) has resulted in expanding the geological knowledge of the Indian sedimentary Basins and about $88 \%$ Basinal areas are at various stages of exploration (DGH, 2011). These efforts have also aided in working out a scheme of tectonic classification of the Basins (Biswas et al., 1993, Biswas, 1998, Ravi Bastia et al., 2007) that was required for the detail Basin analysis. Multifold increase in 3D seismic data acquisition led to many discoveries in challenging environments. Drilling of the deeper exploratory wells resulted in refining the geological models of the existing Basins and better understanding of their tectonic styles, sedimentation pattern and evolution.

Biswas et al. (1993) for the first time published a comprehensive classification of Indian sedimentary Basins using the Dickinson (1976) scheme of Basin classification based on the structural style, geometry and size, nature of stratigraphic fill and thermal history into 38 sedimentary Basins and grouped them in three main settings: (i) intracratonic, (ii) rifted, (iii) orogenic settings (Table 1) and regrouped into 26 sedimentary Basins based on the hydrocarbon proclivity.

Most of the Indian Sedimentary Basins are pericratonic, bordering the Indian plate radially. The northern Basins are bordered by orogenic belts of Himalaya and Assam-Arakan and are the peripheral foreland Basins sub ducting under the orogenic belt. The coastal pericratonic Basins, especially in the south are extending from onshore to offshore and are rifted Basins, separated by horsts. The Intracratonic Basins are rift Basins such as Gondwana Basins/grabens or structural depressions such as Vindhyan, Cuddapah, Kaladgi and Bhîma Basins.

Petroleum occurs mainly in the marginal and pericratonic rift Basins. Occurrence of commercial petroleum from the northern foreland Basin is yet to be established excepting in the Upper Assam interorogenic foreland Basin - Assam Shelf situated on cratonicwedge between Himalayan and AssamArakan mountains. Tectonic setting and collision of the Indian plate created favourable habitat for generation and preservation of thehydrocarbons. Hydrocarbon discoveries from the Interior and Intracratonic rift Basins are so far elusive barring few gas indications; however, recent exploratory efforts are indicating encouraging results such as gas discovery from Proterozoic VindyanBasin.

The estimated prognosticated resource base of the Indian Basins is $28 \mathrm{BMTOE}$ including the 7 BMTOE from deep water sector. As on 2015, exploratory efforts have resulted in estimation of Initial Hydrocarbon In-Place (IHIP) of about 11.18 BMTOE which is about $40 \%$ of the present prognosticated resources. Reassessment of the hydrocarbon 
Table 1: Classification of Indian Sedimentary Basins (After Biswas et al., 1993)

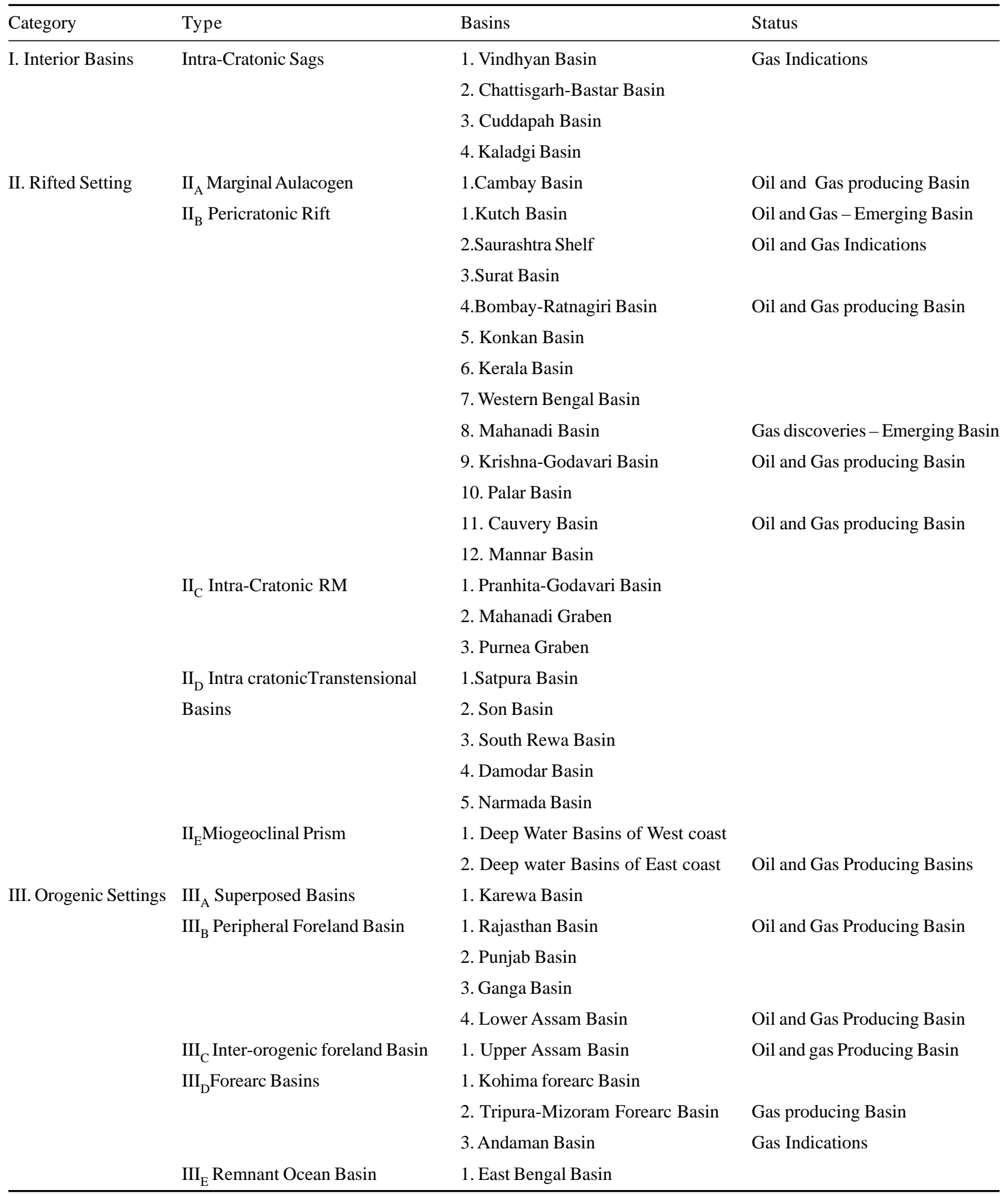

resources of all the Indian sedimentary Basins including the deep water areas has been taken up and is in progress.
Exploratory activities for hydrocarbons in the 26 sedimentary Basins were initiated as early as mid50 's and are continuing with varying degree of success. 
These Basins were grouped under four major categories of I to IV (Rai et al., 1998) (Table 2, Fig. 1) based on the exploration success and commerciality.
Depending upon the exploration results, Basins are upgraded. The number of category-I Basins rose from a single Basin in 1956 (Upper Assam Shelf) to the current 7 producing Basins due to sustained

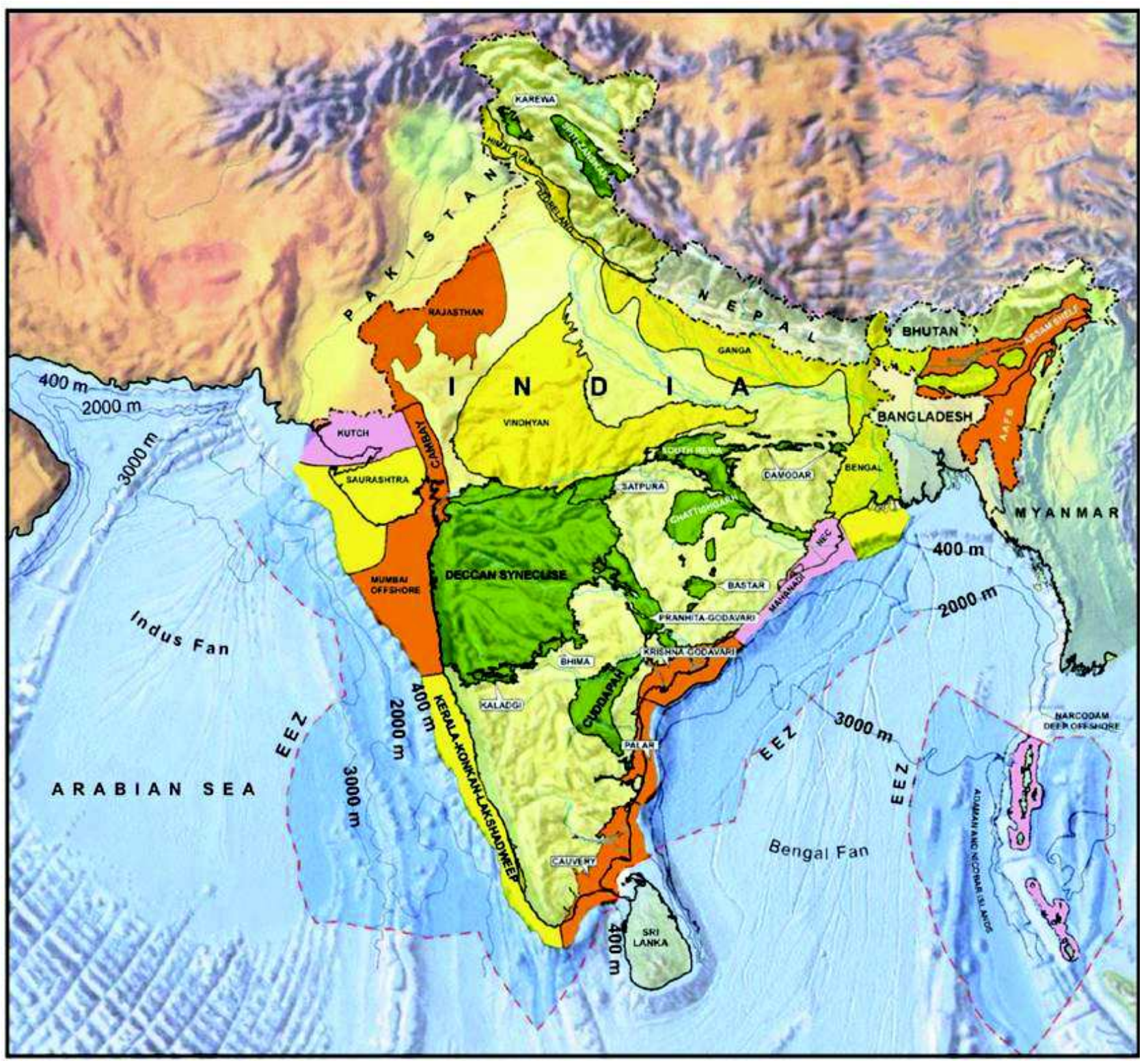

\section{LEGEND}

CATEGORY-I BASIN

(Proven commercial productivity)

CATEGORY-II BASIN

(Identified prospectivity)

CATEGORY-III BASIN

(Prospective Basins)

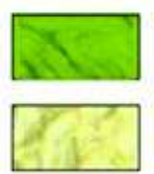

CATEGORY-IV BASIN (Potentially Prospective)

PRE-CAMBRIAN BASEMENT/ TECTONISED SEDIMENTS

DEEP WATER AREAS WITHIN EEZ 
Table 2 : Category of PetroliferousBasins of India

\begin{tabular}{ll}
\hline Category & Basis for categorization of Sedimentary Basins in India \\
\hline I & $\begin{array}{l}\text { Proven Petroliferous Basins with commercial production Assam Shelf, Cambay, Rajasthan, Assam-Arakan fold belt, } \\
\text { Mumbai Offshore, Krishna-Godavari and Cauvery Basins. }\end{array}$ \\
II & Proven Petroliferous Basins awaiting commercial production Kutch, Mahanadi-NEC (North East Coast), Basin, \\
& Andaman-Nicobar Basins. \\
III & Basins geologically considered prospective with hydrocarbon shows Himalayan Foreland Basin, Ganga Basin, Vindhyan \\
& Basin, Saurashtra Basin, Kerala Konkan Basin, Bengal Basin. \\
IV & Frontier Basins which are either poorly explored or having inadequate geological information or are rated poor \\
& based on present concepts and knowledge of petroleum geology but considered prospective by analogy with \\
& similar Basins in the world Karewa Basin, Spiti-Zanskar Basin, Satpura-South Rewa- Damodar Basin, Chhattisgarh \\
& Basin, Narmada Basin, Deccan Syneclise, Bhima-Kaladgi, Bastar Basin, Pranhita-Godavari Basin, Cuddapah Basin
\end{tabular}

exploratory efforts aided with the right technology implementation.

The present paper deals with brief geological set-up, plays established and recent endeavours to enhance success ratio.

\section{Assam Shelf, Assam-Arakan Basin (Category-I Basin)}

The onshore Assam \& Assam-Arakan Basin located in the north-eastern part of India is a poly history Basin which evolved in response to the movement of the Indian plate in relation to the Eurasian and Burmese plates. The Assam, Assam -Arakan Basins cover an area of about 116000 sq.kms. Tectonically, the Assam \& Assam Arakan Basin has been subdivided in to two major Basins viz., Assam Shelf \& Assam-Arakan Fold Belt. Part of the Assam Shelf lying to the north and south of the E-W trending Jorhat Wrench Zone has been designated as North Assam Shelf and the Dhansiri Valley (South Assam Shelf) respectively (Fig. 2).

The North Assam Shelf constitutes platform part of the Basin and represents the shelfal front. The Fold Belt of northeast India is a part of the outer wedge of the Indo-Burmese Arch. It runs through states of Arunachal Pradesh (North Eastern part of NagaPatkai hills), Nagaland (Naga-Patkai hills), Assam (North Cachar hills and Cachar), Manipur (Laimatol Range), and Mizoram (Mizo hills) and to the west open folds of Chittagong-Tripura Hill tracts. Structural complexities and difficult terrain are an integral part of Fold Belt, which have influenced the exploration inputs and exploration strategy for this area.
The North Assam Shelf is extensively explored block of Assam Shelf. Exploration efforts of Fold Belt progressed from anticlinal crest to target subtle structural and geomorphic anomalies viz. Agartala Dome and Banskandi structure based on aerial photos, remote sensing studies and limited $2 \mathrm{D}$ seismic data, yielding fair amount of success.

\section{Hydrocarbon Plays - Established and New Plays}

Oil and gas are established from clastics reservoirs of Mio-Pliocene- Girujan, Miocene -Tipam, Oligocene -Eocene -Barails, Mid-Upper Eocene -Kopilli, Lower Eocene -Lakadong and Therria and from the fractured Archean Basement. The Miocene Oiligocene -Tipam and Barail Formations contain most of the discovered oil.

Exploration of deeper plays (Tura and Basement) has been a major challenge in the Assam Shelf. Tura play (Palaeocene) is an exciting horizon in terms of deeper prospect exploration in entire North Assam Shelf and has potential to emerge as a significant play. Recent exploratory efforts by NOC's has resulted in risk-reward perception of Tura play and identification of prospects in Lakwa and Geleki fields in the northern part of Assam Shelf. There has been significant achievement in establishing fractured Basement and Kopili plays (Eocene) in southern part of the Assam Shelf in Khoraghat area which has opened up new area for exploration of deeper plays in the Assam Shelf.

New age data sets continued to consolidate the Miocene - Tippam Sands and the Barail Play (Oligocene) with identification of new exploration 


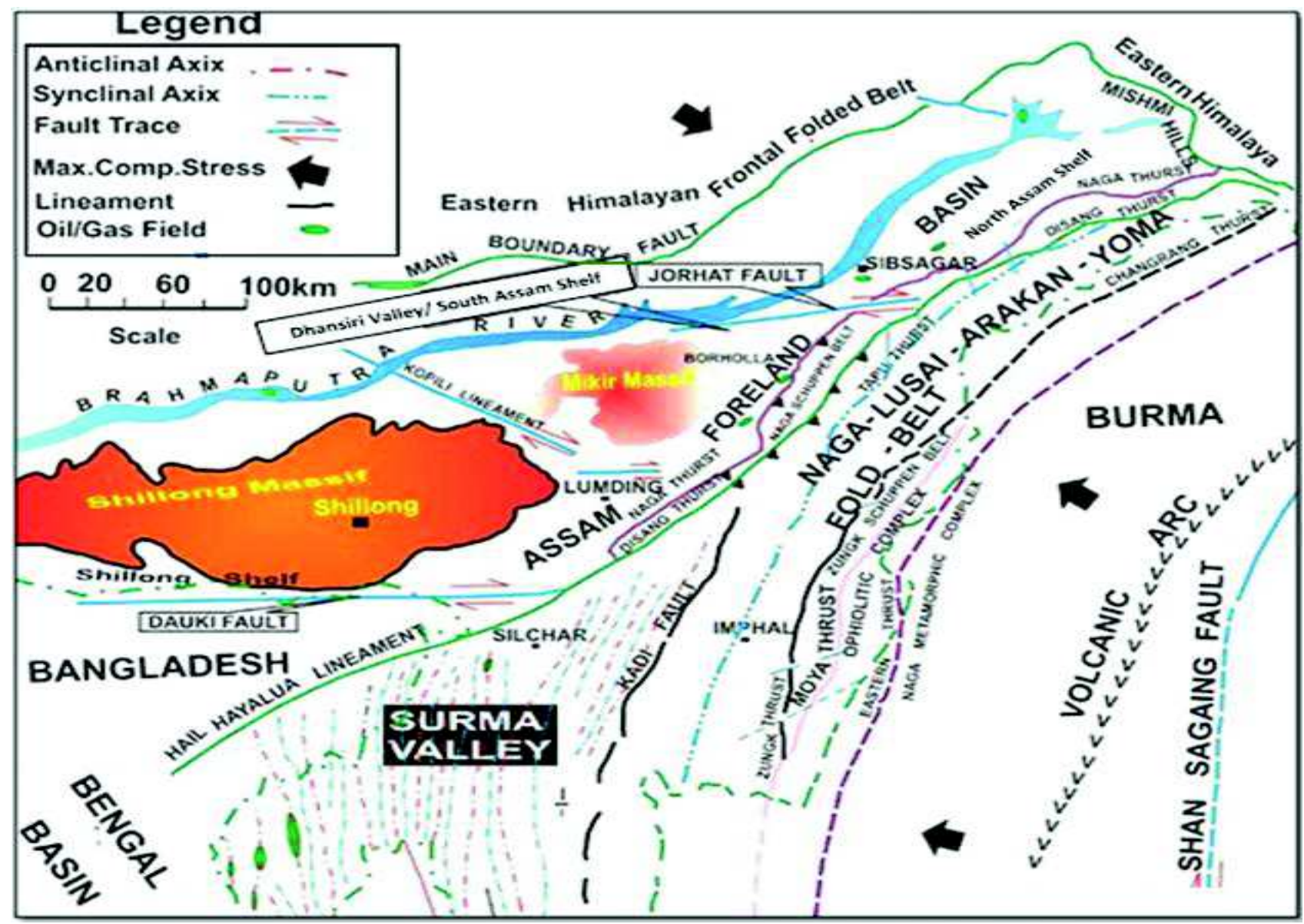

Fig. 2: Tectonic Map of North-eastern India (after ONGC)

prospects. In the southern part of Assam Shelf Sylhet and Kopili plays are well established in BorhollaChampang fields and remain elusive in the rest of Dhansiri Valley.Taking these leads into consideration the focus of exploration is for establishing for Sylhet and Barail plays in the Assam-Arakan Basin. Bokabil play continue to be an attractive stratigraphic exploration play in southern part of Assam Shelf. In Fold Belt, elusive "Badarpur Oil Play" remains to be elusive for oil though few gas discoveries are reported. Naga up thrust Tipam Section has emerged as one of the attractive play in the north Assam shelf. Similarly the basement exploration in Khoraghat area has been rejuvenated with use of new technology DFN modelling (Discreet Fracture Network) and drilling of horizontal wells.

\section{Cambay Basin (Category: I Basin)}

The Cambay rift Basin covering an area of about $53,500 \mathrm{sq} . \mathrm{km}$. is a Category-I Basin and encompasses a narrow, elongated rift graben, extending from Surat in the south to Sanchor in the north. In the north, the Basin narrows, but tectonically continues beyond Sanchor to pass into the Barmer Basin of Rajasthan. On the southern side, the Basin merges with the Bombay Offshore Basin in the Arabian Sea (Fig. 3). Since the discovery of first exploratory well on Lunej structure near Cambay in 1958, more than 2300 wells have been drilled in the Basin by various companies.

\section{Hydrocarbon Plays - Established and New Plays}

The evolution of Cambay Basin from the petroleum point of view is fairly well understood and hydrocarbon accumulations are known in all sequences ranging from Paleocene to Miocene. Major accumulations are known in Middle Eocene structural traps over block uplifts and block edge folds. A few combination traps along block boundaries and over structural noses also occur. Early to Middle Cambay Shale has been established as major source rock,middle Eocene 


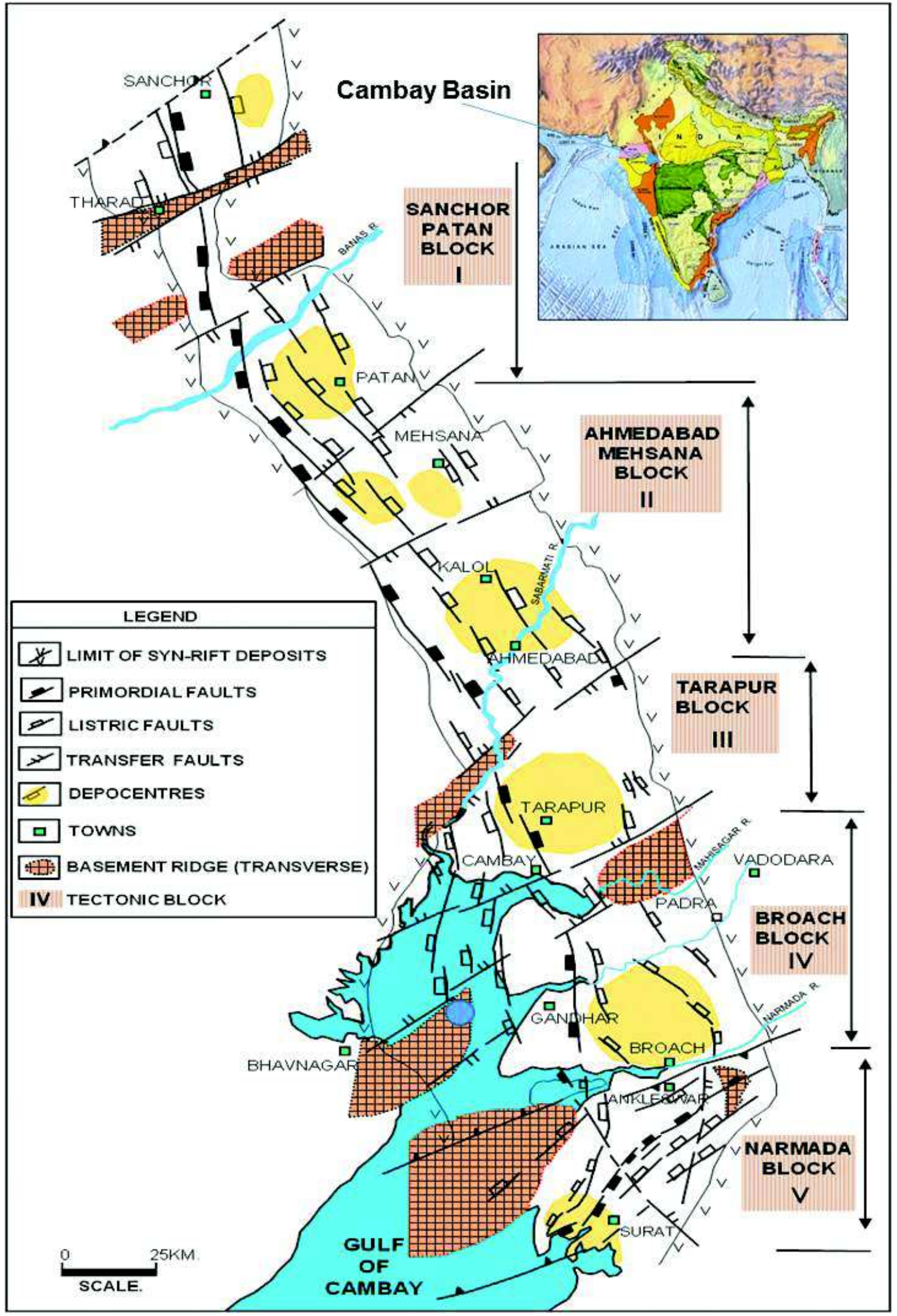

Fig. 3: Tectonic map of Cambay Basin (after ONGC) 
deltaic sands are major reservoirs and Late EoceneOligocene and Miocene Shales are regional cap rock in this Basin. The Broach depression in Broach block is the largest kitchen area for maturation of source rocks and the generation of hydrocarbons. Transverse highs played an important role in controlling the palaeodrainage and distribution of sands. Most of the troughs are local generation centres for accumulation in the adjacent highs. There are several petroleum systems in the Basin and the most important one is the Cambay-Hazad Petroleum System(!) which is related to several large oil and gas fields.

The Cambay-Hazad(!) petroleum system in South Cambay Basin, has original in-place oil and gas reserves of 395 million tonnes. The system covers $9320 \mathrm{~km}^{2}$ encompassing 20 different oil and gas accumulations. Carbon isotopic and biological marker data indicate that the low sulphur, high API gravity oil originated from the lower-middle Eocene Cambay Shale source rock. Burial and thermal history reconstructions indicate that oil generation and migration occurred from Miocene (21 Ma) to Recent. The overburden rocks are over $3 \mathrm{~km}$ thick and range in age from middle Eocene to Recent. The principal reservoir rocks are sandstone units of the Hazad and Ardol Members of the Ankleshvar Formation.

The essential elements of the petroleum system, consisting of the source, reservoir, seal and overburden rocks were deposited from early Eocene to Recent time and the critical processes of generation, migration, trap formation, and accumulation occurred from Miocene to Recent.

Although it is usually the new discoveries that capture the attention of the oil industry, $70 \%$ of the hydrocarbon liquids produced in the world today actually come from fields that have been in operation for more than twenty years: the majority of petroleum assets consist of "old" fields. With most of the world's potential oil provinces having already been explored and major new discoveries becoming increasingly rare, mature fields are slated to play an ever more prominent role in energy supply.

Currently exploration of the Cambay rift Basin is in matured stage and bears a good chance of maximizing the probabilities of discovering small fields in subtle traps. As most of the large accumulations have been located, the Basin is now being rated as low risk/moderate reward category. Growth in oil and gas production expected from a combination of new field discoveries and effective management of existing acreage.

\section{Rajasthan Basin (Category: I Basin)}

The 1,26,000 sq. km of Recent sediment covered area to the west of Aravalli up to Pakistan border which is a part of the Thar desert, is designated as the Rajasthan peripheral foreland Basin (Biswas et al., 1993). It is a part of the Indus Foreland. It is divided into four sub-basins/sectors (Fig. 4) viz., (i) Jaisalmersub-basin (JB) on the north western slope of the Jaisalmer-Mari basement arch (JMA), (ii) Bikaner-Nagaur (BN)subbasin on the northeast flank of the arch, (iii) ShahgarhMiajlar (SM) sub-basin southwest of the arch and (iv) Barmer-Sanchor (BS) sub-basin south of the arch (extension of Cambay Basin). Recent discoveries of oil and gas from this Basin have enhanced the prospectivity perception.

Barmer-Sanchor sub-basin is a lacustrine failed rift comprising the sedimentary sequence of more than $6 \mathrm{~km}$ ranging in age from Mesozoic to Cenozoic with prolific Eocene source rocks. High quality reservoirs are encountered in the Upper CretaceousPaleocenesyn rift deposits. Number of oil and gas discoveries like Saraswathi, Rageshwari, Kameshwari, Mangala, Aishwarya, Shakti, Bhagyam

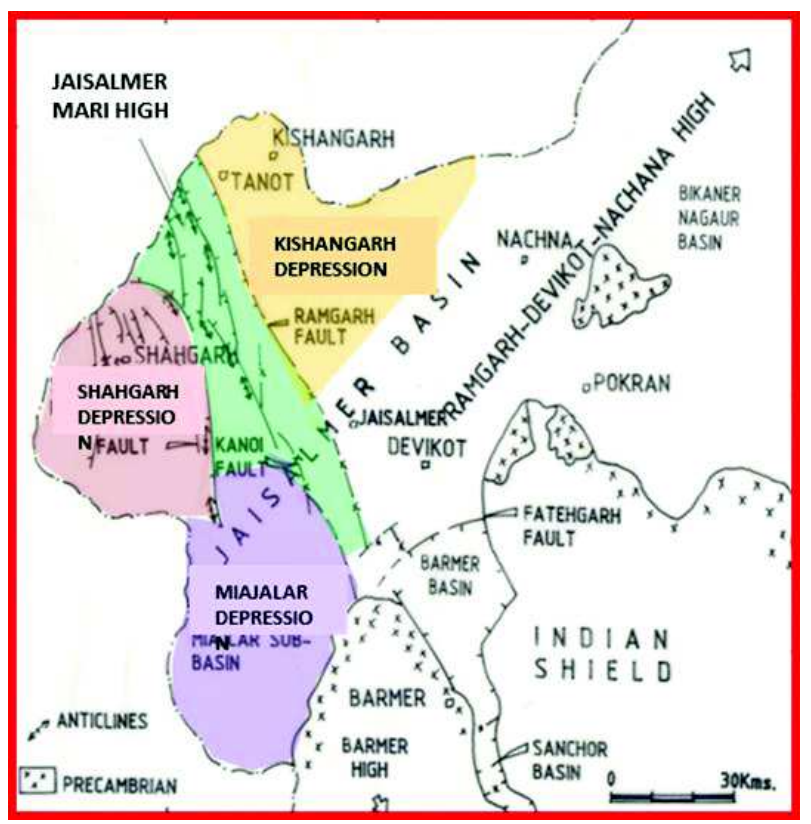

Fig. 4: Sub-basins of Rajasthan Basin (after ONGC) 
are some of the significant fields in Barmer-Sanchor sub-basin.

\section{Hydrocarbon Plays - Established and New Plays}

The Jaisalmer sub-basin is a Late Palaeozoic-Mesozoic Basin with Permian rocks resting unconformably over the Proterozoic Basement with gas discoveries of Manhera Tibba, Ghotaru Extn-I, South Kharatar, ChinnewalaTibba and BakhriTibba fields. The Bikaner-Nagaur sub-basin to the north has widely differing geological histories during Palaeozoic and Mesozoic times. This Basin has well developed InfraCambrian sequence. The Shahgarh-Miajar sub-basin is mainly Mesozoic Basin with thin cap of PalaeoceneEocene rocks $(300 \mathrm{~m})$ and a thin $(200 \mathrm{~m})$ base of Permian rocks resting over the basement.

The Rajasthan Basin is mostly covered by desert sands excepting on the Jaisalmer-Mari basement arch (JMA) which is the only outcropping region besides a few scattered ones. Sequence from Middle Jurassic to Early Eocene is exposed in Jaisalmer sub-basin.

Apart from Barmer sub-basin, there is no Tertiary prospect in other sub-basins of Rajasthan. Excepting small satellite pools in the Paleocene section, the chance of another large discovery appears to be low. However, the Barmer discoveries indicate that the prospect of sizeable accumulation in Sanchor subbasin cannot be ruled out. In Shahgarh-Miajar subbasin, the Mesozoic are the main prospective targets, particularly the Cretaceous Pariwar, Goru, and Parh Formations. Deeper Cretaceous and Jurassic targets should be the primary focus in Shahgarh-Miajar subbasin. In Jaisalmer sub-basin focus should be on combination and subtle traps in Jurassic and Lower Cretaceous plays, while more extensive exploration for heavy oil should be planned for the Bikaner-Nagaur sub-basins.

In Jaisalmer sub-basin, deeper Mesozoic plays like Baishakhi Badesir, Jaisalmer and Lathi of Jurassic age will form frontier plays. The finer clastics along with thin irregular sand bodies within Basisakhi Badesir Formation deposited in sub tidal to inner shelf environment may form stratigraphic/strati-structural prospects which are targets for future exploration. Similarly, the thick Jaisalmer limestone with occasional oolitic development may be another suitable promising exploration objective.

\section{Western Pericratonic Rift Basins}

The Basins of western continental margin of India (WCMI) situated on the western passive margin of the Indian plate evolved during the separation of Madagascar-Seychelles in Late Cretaceous between $90 \mathrm{Ma}$ and $65 \mathrm{Ma}$. The rifting started in Late Cretaceous with syntectonic Deccan volcanic activity that continued till Early Paleocene. Early Paleocene to Early Eocene hiatus was the period of the rift-drift transition marked by a widespread unconformity in all the Basins. The post-rift thermal cooling resulted in sagging and the Basins evolved into a marginal sag initiating marine transgression.

Coast parallel Ridge-Depression couplets, KoriComorin Ridge/Depression and Laxmi-Laccadive Ridge/ Depression, crossed by first order transverse basement arches are the major features of the WCMI structure (Biswas, 1989) (Fig. 5). The transverse

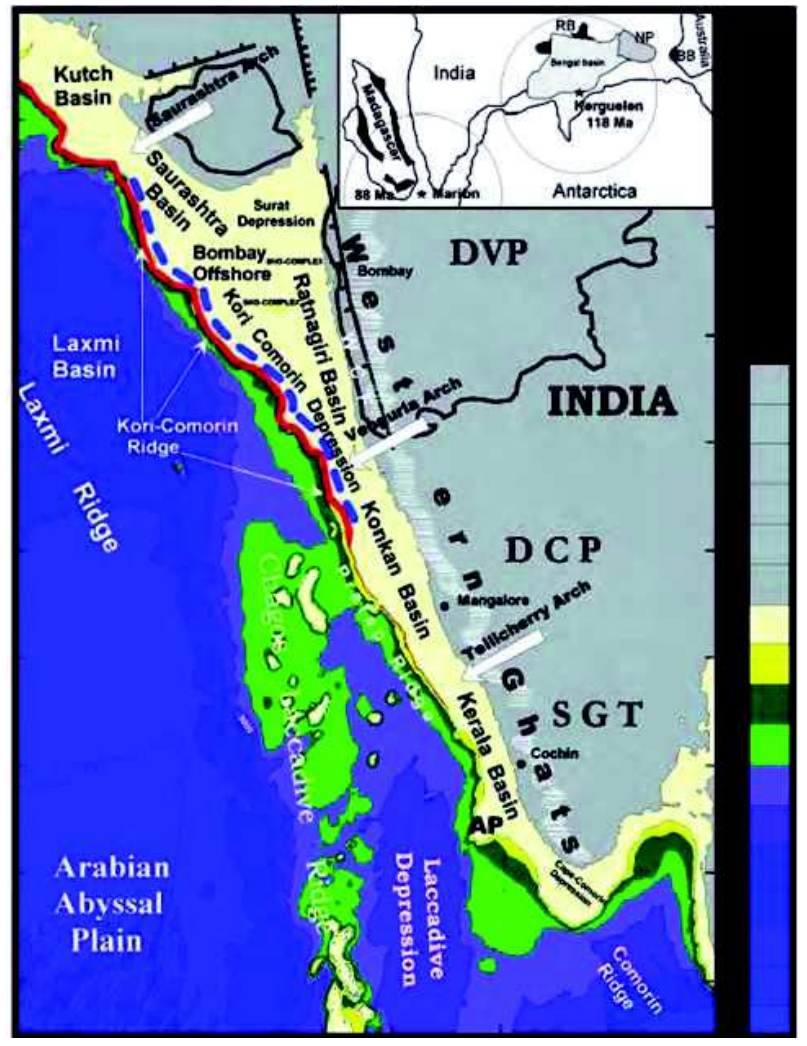

Fig. 5: Tectonic map of Western Continental Margin of India (modified after Biswas, 2008b) 1: Saurashtra Arch; 2: Bombay Arch; 3: Vengurla Arch; 4: Tellicherry Arch. Basin positions: - N of 1- Kutch Basin, Between 1 \& 2: Surat Depression, 2 \& 3: RatnagiriBasin, 3 \& 4: Kankan Basin, $S$ of 4: Kerala Basin. SHG-Complex: Shelfal horst graben complex (after ONGC) 
arches, from north to south are, Saurashtra, Bombay, Vengurla and Tellicheri arches which divide the shelf into five offshore sub-basins - Kutch, Surat, Ratnagiri (Bombay offshore Basin), Konkan and Kerala Basins (Biswas and Singh, 1988). Kori-Comorin couplet marks the edge of the present continental shelf, which is rifted developing a "shelfal horst-graben" complex. Each sub-basin extends offshore across the shelf, depressions and ridges. Thus, a shallow shelfal horstgraben complex, a shelf margin depression and ridge, a deep slope-parallel depression and an outer ridge (Laxmi) separating the Basin and abyssal plain are the characteristic structural domains of each subbasin. Kerala, Konkan and Ratnagiri Basins are confined to offshore. The West Coast Fault terminates these Basins along the coastline.

Of the five sub-basins, Surat and Ratnagiri (Bombay) offshore Basins qualify as a Category-I Basins with its vast reserve of hydrocarbon contributing almost $70 \%$ of India's total oil/gas production. Kutch Basin is Category-II Basin waiting to be upgraded in view of commercial discovery.

The Kerala-Konkan Basin though well explored no commercial accumulation could be located till date. Awaiting discovery, this Basin is listed in CategoryIII Basins.

\section{Mumbai Offshore Basin (Category-IBasin)}

The Mumbai Offshore Basin is the most prolific of all the hydrocarbon bearing provinces in India.

Bounded by Diu and Narmada Faults and Deccan Trap outcrops to its north and east, the pericratonic Mumbai Offshore Basin extends towards west parallel to the western continental margin of India up to the Western Margin Basement Arch. NE-SW trending Vengurla Arch separates the Basin from the Kerala-Konkan Basin to its south.

On the basis of structural elements and the nature of sediment fill which influenced characteristic hydrocarbon generation and entrapment patterns in different sectors, the Basin is subdivided in to a number of blocks, viz. Tapti-Daman block, Diu block, HeeraPanna-Bassein block, Mumbai High-Deep Continental Shelf block, Shelf Margin block and the Ratnagiri block.

Based on tectonic-sedimentary history and alignment of structural elements, the Basin is subdivided in to six major units, three of which are characterised by paleo-platform set up, viz. the Mumbai High-DCS platform, the Heera-PannaBassein Platform and the Ratnagiri platform which were dominantly filled up by carbonate sediments. Three of the other units, viz. Murud low, Saurashtra rise- Diu depression and Surat depression are mostly characterised by clastic sedimentation acting as the dominant hydrocarbon generation centers for the Basin. The Tapti-Daman block is a clastic Basin developed in the northern part of Bombay Offshore Basin in front of a narrow Cambay Gulf having sedimentation history from Paleocene time onwards. Middle Eocene-Oligocene deltaic sediments of protoNarmada in Cambay Basin and Late OligoceneMiocene sediments in Tapti-Daman sector deposited as a result of progradation of the delta through the narrow Cambay Gulf.

Continued and sustained exploratory and development efforts in Mumbai Offshore Basin since last four decades have shown remarkable results and led to conversion of nearly $50 \%$ of the prognosticated resource of $9190 \mathrm{MMToE}$ in to In-place volume of hydrocarbons.

\section{Hydrocarbon Plays - Established and New Plays}

The major hydrocarbon fields of the Basin include Bombay High, Bassein, Panna, Mukta, Neelam, Heera, South Heera, Ratna, D-1 fields, Tapti (north, mid and south), C22/24 structures.

Hydrocarbon accumulations in BH-DCS-HPB (Bombay High-Deep Continental Shelf-HeeraPanna-Bassein) sector are structurally controlled, in general occur, in carbonate reservoirs ranging in age from Middle Eocene to Middle Miocene with a few exceptions of stratigraphic/combination plays in clastic reservoirs. While major pay zones occur in Middle Eocene and Early Miocene plays, hydrocarbon zones have also been identified in Paleocene to Oligocene plays where as in Tapti-Daman sector Daman (Late Oligocene) and Mahuva (Early Oligocene) plays are well established.

Targeting new objectives in established areas and looking for extension of known plays besides exploring deeper plays has always been the essence of exploratory activities in Mumbai Offshore Basin. 
Recent successes in Basement and Basal clastic section from a number of wells on west and southern periphery of Mumbai High have seen renewed focus and exploration initiatives being adopted for exploration of this play. With integrated interpretation of seismic and well data including special analysis of cores and image logs along with application of state- ofthe-art technologies for fracture imaging, a significant improvement has come in identification and mapping of probable fracture zones in basement. Simultaneous exploration for extension of other known plays in LIII to L-VI limestones of Early Miocene to Late Oligocene age beyond the known confines around Mumbai High is also expected to discover more hydrocarbons.

Exploring for Eocene - PaleocenePannaclastics in recent times in areas away from known accumulations has shown very positive results around south and south east of Mumbai and Heera-PannaBassein platforms.

Renewed efforts of targeting deeper as well as established plays and success achieved in new areas have helped in more resource conversion.

The established plays in Early Oligocene to Mid/ Late Eocene Carbonate reservoirs of Mukta and Bassein Formation along with fluvio-marine clastic deposits of early Eocene/late PaleocenePanna Formation continue to attract exploration.

A recent discovery of gas in the very fine grained Pliocene reservoir towards west of the Neogene Shelf margin of Mumbai Offshore block from shelf edge roll over structure opened up a new play in the frontier area.

Discovery of deeper oil, below the known oil water contacts, especially in Bombay High sector opened up new vistas of exploration.

Exploring the Mahuva Play in B-12/C-24 and $\mathrm{C}-26$ areas remained as challenge due to HP-HT conditions besides the establishment of the deeper plays (Belapur, Panna and Basement) though proved prospective in few wells.

\section{Kutch Basin (Category-II Basin)}

The Kutch Basin located on the western continental margin covers an area over 80,000 Sq. Km both on- land and off-shore. The Basin is a poly-history rift and passive margin Basin which has evolved through multiple rift phases after the separation of the Indian and African plate. Exploration commenced wayback in 1972 and decade later oil was discovered in the offshore KD structure from Eocene Limestone.

The onland part of the Kutch Basin appears to be an arm of a failed rift system and is restricted by the Allabandh fault towards the north and extends up to the North Kathiawar fault towards south. The structural trend on the onland part of Kutch Basin essentially trends in an east-west direction where as in the offshore part of the Basin the dominant structural trend appears in a NW-SE direction. This indicates that probably the separation of the Indian and African plates has a more significant imprint in the offshore area. Based on the study of recent gravity magnetic data it appears that the continental oceanic boundary took an easterly swing around Kutch Basin, distinctly indicating possible presence of Mesozoic sediments below the Deccan traps even in the Deep water areas (Fig. 6).

The most important plays in the Kutch Basin are sub-trappean Mesozoic's and Early Tertiary Sediments.

\section{Hydrocarbon Plays - Established and New Plays}

The early discoveries in Kutch Basin include oil in Eocene limestone and calcareous sandstone from KD area, gas discovery in Early Cretaceous sandstone in GK-22 area, gas in late Cretaceous marl from GK39 and from Palaeocene sands in GK-29 area. Discoveries made in Tertiary sections have ushered in a paradigm shift in the thought process for exploration in the area. Recent discoveries from Mesozoic sediments south of Kutch Basin on the northern flank of Saurashtra Arch has established the presence of active petroleum system south of the North Kathiawar fault and corroborates with the envisaged prospectivity till Saurashtra arch in the south. Discovery of gas from GK-28 structure from Deccan basalts opened up a new play.

\section{Eastern Pericratonic Rift Basins}

The Eastern Pericratonic Basins (Fig. 1) define the present coastal and offshore structural framework that evolved since Late Jurassic related to the break 


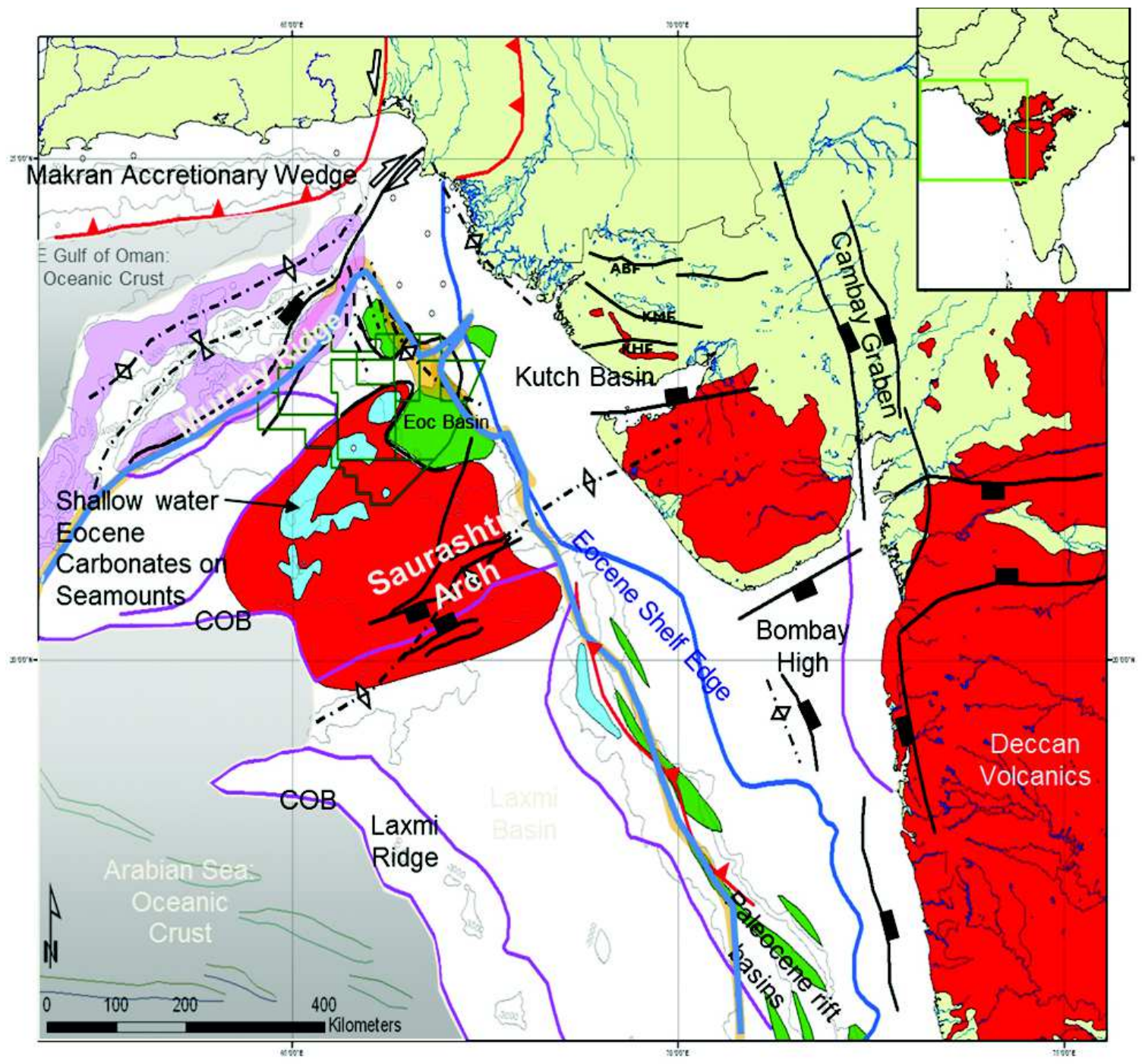

Fig. 6: Tectonic map of West coast of India Showing the Kutch Basin (after ONGC)

up and drifting of Indian and Antarctican plates (Biswas, 2008b). The eastern continental margin evolved by segmentation into a rifted northern part and southern sheared (transformed) part (Shyam Chand and Subrahmanyam, 2001). Whereas the rifted northern part, Bengal-Krishna Godavari is characterized by sedimentary Basins having coast parallel horst-graben structures, the Cauvery Basin along the sheared segment shows development of pullapart Basins and intervening ridges oblique to the $\mathrm{N}$ $\mathrm{S}$ shore-line. The Basins formed on the eastern passive margin of the Indian plate in a divergent set up. The continental shelf is narrow here and the Basins pass into deep-water slope to abyssal Eastern Ocean Basin (EOB) of Bay Bengal ( $400 \mathrm{~m}$ to $2000 \mathrm{~m}$ ) within a short distance (Fig. 1). The Basins from north to south are:
Remnant ocean Basin of Bengal (Biswas et al., 1993), Mahanadi, Krishna-Godavari (KG), Palar, Cauvery, Mannar rift Basins and Andaman. Of these, KG and Cauvery (including Palar and Mannar Basins) are category-I Basins and Mahanadi and Andaman are category-II. The Bengal Basin still remains as category-III Basin.

\section{KG Basin (Category-I Basin)}

The Krishna-Godavari Basin constitutes a typical passive margin Basin and has a polycyclic (dual-rift province) evolution history (Fig. 1 and 7). Basin comprises a wide array of sedimentary facies from early Permian through Cenozoic with the analogous outcrops defining the Basin limitation, along the north 


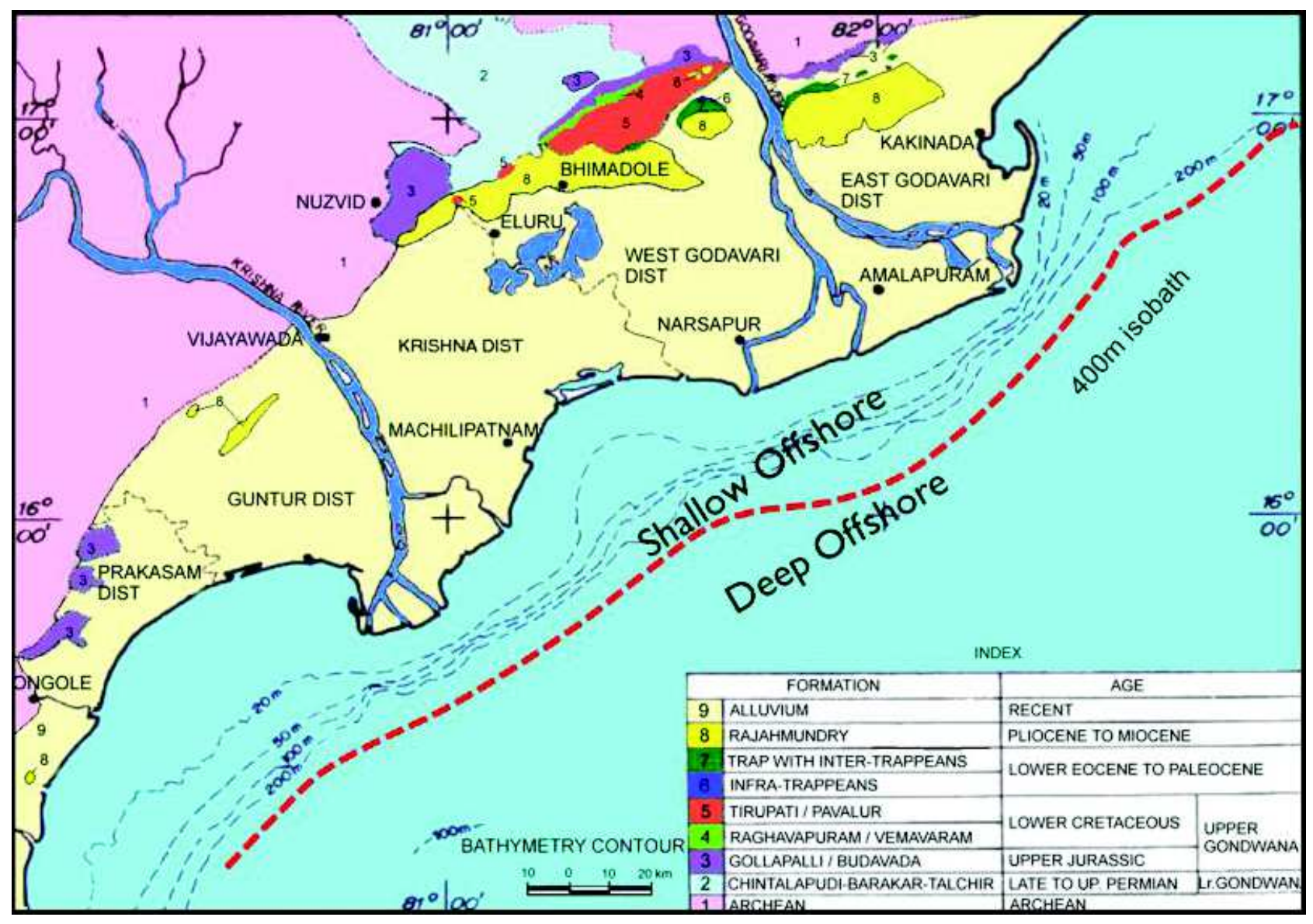

Fig. 7: Geological Map of Krishna-Godavari Basin (after ONGC)

western part of the Basin.

It is spread over an area of $28,000 \mathrm{sq} . \mathrm{km}$. in the on land and $1,45,00$ sq.km (24,000 sq. km. up to $200 \mathrm{~m}$ isobath) in the Bay of Bengal offshore. The prospective area for oil \& gas exploration in on land covers the three coastal districts of East Godavari, West Godavari \& Krishna and in Offshore till $85^{\circ}$ East ridge. Efforts by both NOC's and Private oil companies have unlocked huge hydrocarbon reserves.

The Basin is estimated to have a sediment thickness in excess of $7.0 \mathrm{Km}$. Broad tectonic expression of the Basin comprises linear horst-graben system, growth fault/rollover and block tilting along synthetic fault over intra shelf regime followed by toe thrusting exhibiting typical evolution from rift Basin to passive margin Basin. The habitat of hydrocarbons spreads over a wide stratigraphic spectrum from Triassic to Pliocene and geographical distribution, on land, offshore including ultra-deep water domain
(Fig. 8).

The major plays established in KG Basin are Mandapeta (Permo-Triassic), Syn-Rift Gollapalli/ Nandigama/Kanukollu (Late Jurassic to Lower Cretaceous, Raghavapuram (Early-Late Cretaceous), Pasarlapudi/Vadaparru (Late Palaeocene to Eocene), Matsyapuri/Ravva (Oligocene to Miocene) and Godavari (Pliocene). Both biogenic and thermogenic petroleum system are operative in the Basin.

\section{Hydrocarbon Plays - Established and New Plays}

The exploration efforts by various operators have brought out that the synrift play as one of the most significant hydrocarbon bearing play in KG Basin. Improved 3D seismic imaging and better understanding of the geological evolution resulted in discovering of oil and gas from syn rift sequences, both onland and offshore, including the deep water sector. Reservoirs, invariably from the complex 


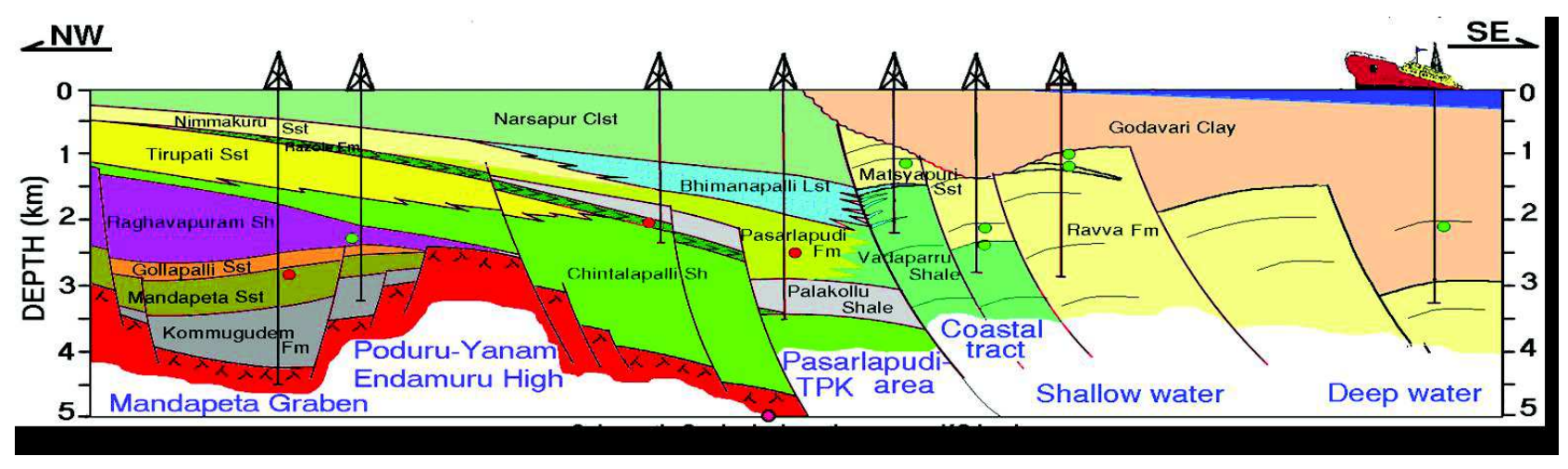

Fig. 8: Geological Cross section across KG Basin showing the hydrocarbon habitat (after ONGC)

sequence of synrift or more aptly Gollapalli Formation are tight in nature and hydro-fracturing may improve the productivity. Synrift reservoirs in KG Basin exhibit low porosity and permeability with some sweet spots. The play at deeper depth exhibit high temperature (> $\left.400^{\circ} \mathrm{F}\right)$ and high pressure $(>70 \%+$ hydrostatic) conditions challenging the current technical limits.

Recent discovery of oil from synrift play in Krishna river mouth area (Nizampatnam bay) has opened up a new area albeit with a challenge of tight reservoirs.

The Basin has distinction of reporting maximum number of discoveries in the last decade. (DGH: 200515).

Subsequent to discovery of a large Dhirubai gas field (DGH, 2005) by Reliance Industries Ltd., ONGC notified a large gas field from the ultra-deep waters in 2006. As such, this Basin has shown a very high degree of hydrocarbon potential, particularly in deep waters off the Godavari river mouth, essentially from Mio-Pliocene \& Pleistocene Formations. Similarly, recent discoveries of gas from Machilipatnam bay area from Eocene-Pliocene Formations from shallow water segment endorses for sustained exploration. Based on trend of discoveries, there are good chances of discovering large fields, especially from deep water segment.

In KG deep waters mainly slope-channel-leveecomplex, debris flows, low stand wedge and Basin floor fan complexes remain as major targets. In shallow water growth fault related structures, channel fills combination traps, upper slope fans still remain as attractive plays particularly in the delta-slope transition. In on land, the deeper syn rift plays remain as major attractive play. Based on the emerging exploration trend, sands within the Lower to Upper Cretaceous Raghavapuram play attain importance for further exploration.

Major hydrocarbon disocveries in KGultra deep water sector subsequent to Ultra Deep (UD) biogenic gas discovery are elusive, exploration density in the sector is meagre and the area still remains a "frontier area" and warrants further exploration specially for biogenic petroleum system.

\section{Cauvery Basin (Category: I Basin)}

Cauvery Basin is pericratonic Basin, evolved due to rifting between India and Sri Lanka during the breakup of Eastern Gondwana land (Katz, 1978) during Late Jurassic-Early Cretaceous and subsequent drifting (Late Aptian) of Indian plate from Gondwana land along NE-SW oriented Eastern Ghat trend. The rifting has created several horsts and grabens. The present day horst and graben picture of MesozoicCenozoic stratigraphic column have been related to two principal tectonic episodes namely, extension stage during Late Jurassic - Early Cretaceous and thermal subsidence stage during late Cretaceous to Cenozoic. Cauvery Basin has been divided into sub-basins, namely Ariyalur-Pondicherry, Tranquebar, Nagapattinam, Tanjore, and Ramnad-Palk Bay separated by Kumbakonam-Madanam, PattukottaiMannargudi \& Mandapam-Delft ridges (Fig. 9).

The potential source in the Cauvery Basin is envisaged to be the Synrift Andimadam sediments along with contribution from Sattapadi and Bhuvanagiri sediments. Source rock is generally Type-II \& Type- 


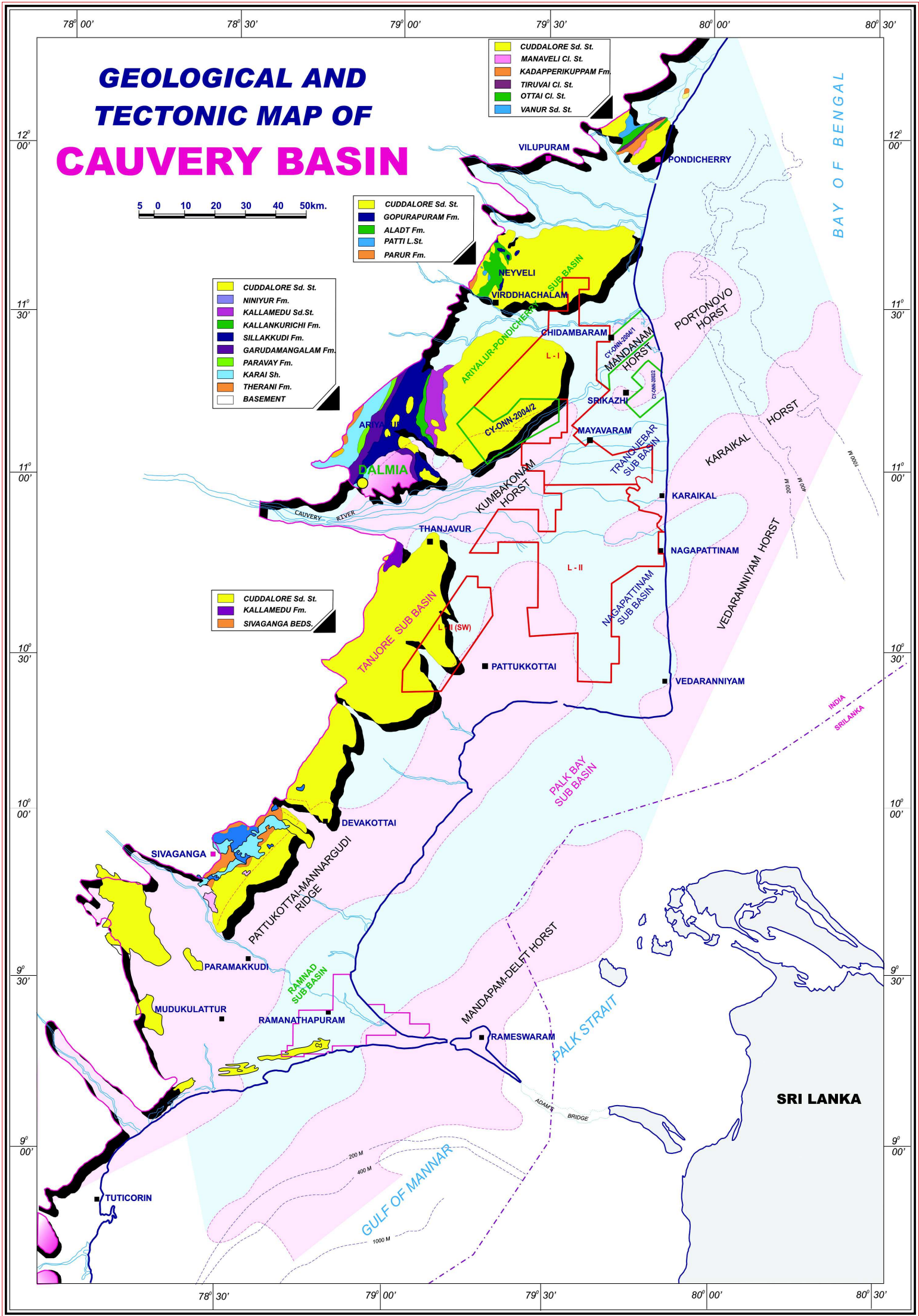

Fig. 9: Geological and Tectonic map of Cauvery Basin - East coast (after ONGC) 
III capable of generating both liquid \& gaseous hydrocarbon. Two sets of faults, one trending NESW and associated with the Synrift phase and the other NW-SE fault system dissecting the older system are envisaged to have played major role in the depositional setting, hydrocarbon migration and accumulation.

Concerted efforts to explore the Basement play resulted in major success with discovery of hydrocarbons from Madanam, Pandanallur and Chidambaram areas.

\section{Hydrocarbon Plays - Established and New Plays}

Basement Play: Exploratory drilling in Madanam and Pandanallur areas established the commercial hydrocarbons from basement play in Cauvery on land area.

The other important operative plays in Cauvery onland are - Andimadam Play : (prolific producer in
Kuthalam-Kali, Pallivaramangalam-Vijayapuram, Periyakudi fields and is characterised by poor porosities and low permeabilities). Bhuvanagiri Play: (Well established in Pallivaramangalam Vijayapuram, Pundi, Kanjirangudi and Periyapattinam fields tight reservoirs), Nannilam Play (in most of the wells drilled in Ariyaluru-Pondichery sub basin,well established in Nannilam, Tiruvarur, Kanjirangudi, Periyapattinam, Perungulam and PBS fields) Kamalapuram Play (The Paleocene play is well established in Adaiyakkamangalam, Kamalapuram, Nannilam, Kuthanallur \& few fields in Ramnad subbasin).

Recent discovery of Periyakudi field from synrift sequence gave a major impetus to synrift play and chance of discovering large fields in the Basin. However, as in the case of Krishna-Godavari, this play is also known for HP-HT conditions.

In Cauvery Offshore, there is no much

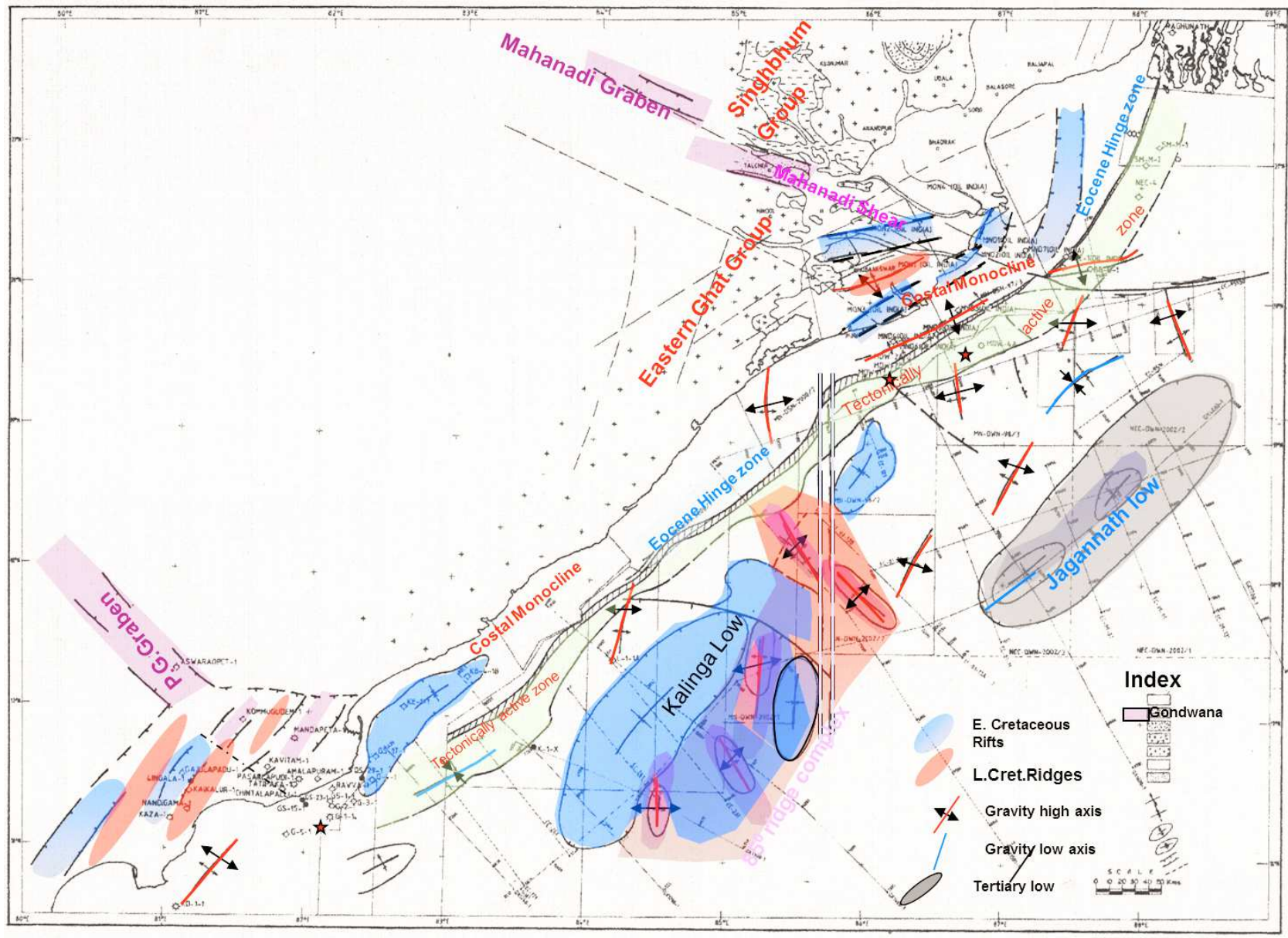

Fig. 10: Geological and Tectonic Element map of Mahanadi Basin (after ONGC) 
breakthrough except in the established PY and PH fields. Recent discoveries reported by Hardy Oil in Cauvery shallow water, by Reliance Industries Ltd (RIL) in Cauvery deep waters (discovery of thick column of gas \& condensate from synrift sequence from the CY-PR deep water area) and Cairn Energy India Ltd (CEIL) from Srilanka/Gulf of Mannar Basins has rekindled the exploration interest in the Cauvery Offshore.

\section{Mahanadi Basin (Category-II Basin)}

Mahanadi Basin is a category-II sedimentary Basin located in the Eastern Passive Continental Margin of Indian sub continent. Geographically, it is flanked by the Bengal Basin in the NE and Krishna-Godavari Basin in the SW. The on-land part of the Basin encompasses the deltaic plains of Mahanadi river and its distributaries lying between Jagannathpur in the northeast and Chilka Lake in the southwest which extends in to offshore Bay of Bengal covering a total area of about 2,60,000 sq.kms.

Tectonically, Mahanadi Basin is a poly-history Basin - starting as a NW-SE trending Permo-Triassic Gondwana rift characterised by a failed arm superposed by Late Jurassic-Early Cretaceous NESW trending east coast rifting and finally leading to passive margin Basin set-up during Late Cretaceous - Recent period.Various sub-basins/depressions with NE-SW trend are present which include CuttackChandbali depression, Paradip depression, Puri depression, Northern and Southern offshore depression with sediment thickness varying from $5000 \mathrm{~m}$ in on land to more than $10,000 \mathrm{~m}$ in the offshore Basin(Fig:10).Exploration process started in Mahanadi Basin way back during $1960-70$ by OIL and ONGC. Fifteen exploratory wells have been drilled with no major hydrocarbon interest reported.

With the advent of New Exploration Licensing Policy (NELP), the exploration efforts were rejuvenated and additional inputs in terms of seismic API and drilling was carried out by NOC and Private E\&P companies and number of gas discoveries were made in the offshore part of the Basin.

\section{Hydrocarbon Plays - Established and New Plays}

Most of the gas discoveries in Mahanadi offshore Basin are Non-Associated Natural Gas (NANG) and biogenic in origin from Mio-Pliocene channel plays. In Oligocene-Eocene level only two wells encountered gaseous hydrocarbon of mixed origin. In all the cases the hydrocarbon bearing clastics reservoir facies are of limited areal extent. New plays- deeper fan prospects of Cretaceous and Paleocene age could not be probed due to severe down-hole complications related to high-pressure. The delta- prodelta sequence at the shelf edge is prospective for potential petroleum system in this Basin. In the offshore area MioPliocene shales and channel sands in channel-levee complex on paleo-continental slope suggest prospective source-reservoir combination which is proved by the discoveries.

Exploratory efforts till date are restricted up to the Neogene level. Hence, the Low stand deep-water canyon fill deposits and the associated relict structures of Eocene age and the slope fans of Palaeocene and Eocene age remain as prospective candidates for future exploration targets in this area.

\section{Andaman Basin: (Category-II Basin)}

The area of Andaman Nicobar Island is approximately $6000 \mathrm{Sq}$. Km. The offshore extension forms a sedimentary Basin which occupies an area of more than 75,000 sq.km including the deep water segment. The Basin formed in intra-oceanic setting as an island arc in a convergent set up where the Indian plate is subducting under the Burma-Malayan plate since Cretaceous time. It is a typical island arc with an outer trench, fore-arc Basin, an inner volcanic arc and a back arc Basin (Fig. 11 and 12).

The Andaman fore-arc Basin is sitting on the subduction prism represented by outer sedimentary arc (Roy and Das Sharma, 1993). Thick Palaeogene flysch overlain by shallow marine Neogene sediments are exposed in the islands of Andaman and Nicobar.

\section{Hydrocarbon Plays - Established and New Plays}

The first gas discovery from Miocene Limestone (AN$1-1$ ), the see pages in the islands and oil/gas shows in the mud volcanoes indicate presence of hydrocarbon in the Tertiary sediments. Two petroleum system are envisaged to be operative in the area, the biogenic shallow gas and the deep thermogenic system. These petroleum systems are envisaged to be operative in fore-arc Basin where exploration wells have been 


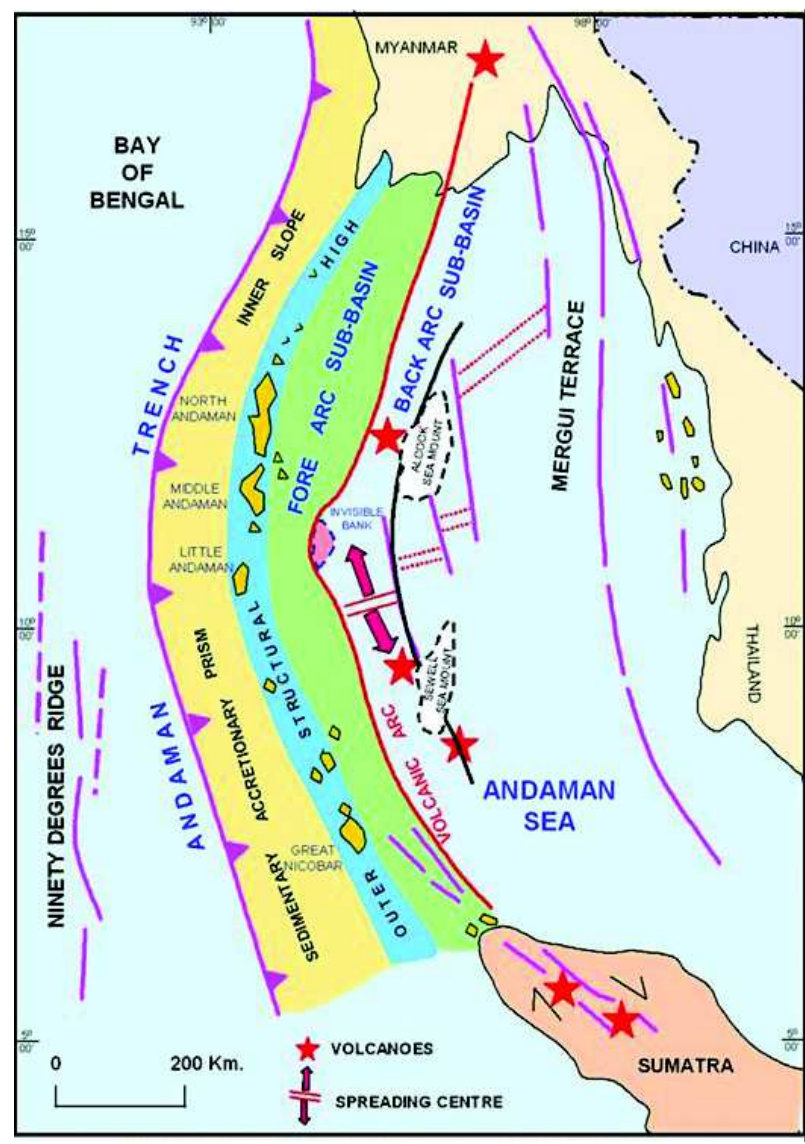

Fig. 11: Tectonic and Basin set-up of Andaman Basin (after ONGC)

drilled; the petroleum systems in the back-arc Basin are conceptual in the absence of well data and are analogue from the adjoining well established North Sumatera Basin with large fields like Arun and Perlak in Indonesia and Yadana, Yetagun fields of Myanmar The main source rocks in this Basin are the Cretaceous and Palaeocene shales of Baratang Formation. The reservoir rock established so far is the Mio-Pliocene Long Formation. Presence of a completely unexplored rift set-up in the southern part of eastern extension of Andaman Island is the future exploration target.

\section{Category III Basins}

Besides the above described major Category-I and Category-II Basins, extensive exploration activities are being carried out in Basins which are geologically considered prospective but so far indicated only presence of hydrocarbons and such Basins are categorised as Category-III. Current exploratory endeavours are to upgrade these Basins to either Category-II or Category-I Basins. Brief summary of the geological setting and status of exploration of some of the Basins is discussed below:

\section{Himalayan Foreland and Ganga Basin: (Category-III Basin)}

Himalayan Foreland and Ganga Basin are on the northern passive margin of the Indian plate which is undergoing sub-duction. Major portion of passive margin had been sub-ducted and in the foreland part only palaeo-Basin margin sediments (Late Proterozoic and Early Palaeozoic Vindhyan Group) covered by huge thickness of post-collision molassic sediments (Siwalik Group) are present. These Basins are being explored since long but excepting a few gas shows,

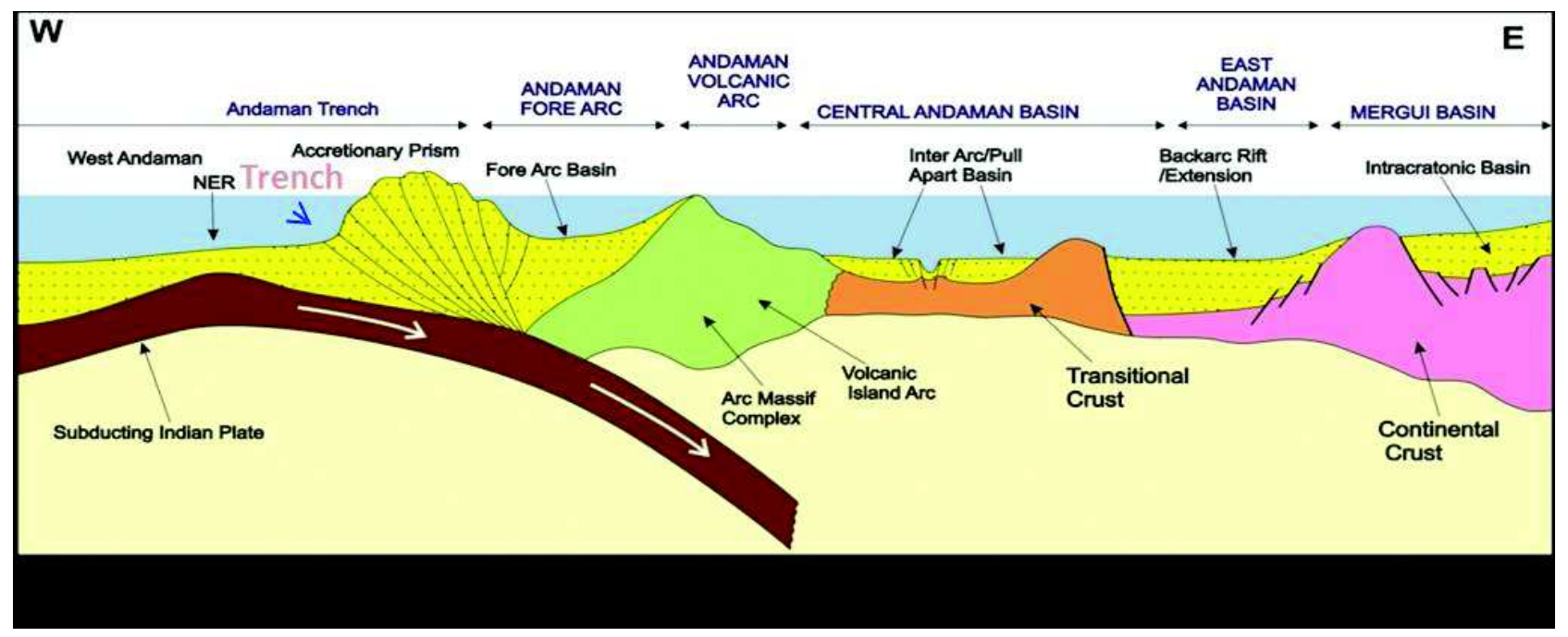

Fig. 12: Geological Cross section across Andaman sub-duction zone (after ONGC) 
no other encouraging result was found. The main target here is the palaeo-passive margin Eocene wedge-out which are expected to be matured in the deeper part of the sub-duction zone. Eocene wedges were encountered in drilled wells in Arunachal and Punjab respectively on the eastern and western extremities of this peripheral foreland area with local shows.

The Himalaya in northwest India is divided into different litho-tectonic blocks by a number of E-W regional boundary thrusts. Exploration in the Himalayan Foreland Basin commenced in the 50's and ONGC drilled about 31 wells. The various structural plays envisaged in a fold thrust belt have been targeted and explored within the hanging wall blocks of Jawalamukhi Thrust and the triangle zone structures with limited success which proved existence of thermogenic gas in the area, albeit in noncommercial quantities.

\section{Hydrocarbon Plays : Established and New Plays}

Majority of the wells drilled in the Himalayan Foreland explored the triangle zone structures and the Jawalamukhi play, where live gas seepages are well known. Gas analysis of Jwalamukhi pool indicates to be secondary with deep gas migrating upward. Based on the exploration efforts so far, inner part of the inner tectonic belt and sub thrust prospects of Palampur thrust in Lesser Himalayas are envisaged as future exploration targets.

\section{Vindhyan Basin (Category-III Basin)}

The VindhyanBasin is situated between the Delhi Aravalli orogenic belt to the north-west and SonNarmada Geofracture to the south. The Bundelkhand Massif, located in the north-central part of the Basin, divides it into two sectors: Chambal Valley to the west and Son Valley to the east (Fig. 13). Proterozoic Vindyhan Basin is one of the frontier areas of exploration in the central part of the country where presence of dry non-sour thermogenic gas has been established from very tight carbonate and clastic reservoirs.

\section{Hydrocarbon Plays : Established and New Plays}

Although the Basin has been under exploration for more than six decades, significant discovery of thermogenic gas from Lower Vindhyan Rohtas
Limestone was made from well Nohtain the year 2012 in the Son Valley sector. Exploratory efforts further led to another gas discovery from Lower Vindhyan Mohana Fawn Limestone in Damoh area in addition to establishing flow/presence of gas from multiple reservoirs within Upper, Middle, Lower Rohtas carbonate units. Lower Vindhyan and Basal Kaimur sandstone reservoirs of Upper Vindhyan sequence are the future targets of exploration.

The other category -III Basins are KeralaKonkan Basin in the West coast and Bengal Basin in the east coast. Presences of non-commercial hydrocarbons are known from these Basins but are yet to open up.

In Kerala-Konkan Basin gas shows were reported from the Tertiary sequence mostly from Miocene and Eocene formations. Though various data sets indicate presence of subtrappean Mesozoic Basin but its hydrocarbon potential is yet to be confirmed.

The poly history Bengal Basin was initiated as intracratonic rifted Basin during late - Paleozoic and Mid-Mesozoic time and received the continental sediments and ended with wide spread Rajahmahal continental volcanic activity. The second phase along with drifting of the Indian plate and the pericratonic part on the eastern margin continuously subsided and received colossal volume of sediments from Late Mesozoic through Tertiary to Recent times.

Commercial success is still eluding however, indications of oil has been observed from Oligocene sands. Recent gas shows from the Gondwana sediments in the Basin marginal part indicate the presence of deep Basin gas from Gondwana rocks buried under thick Cretaceous and Tertiary sediments.

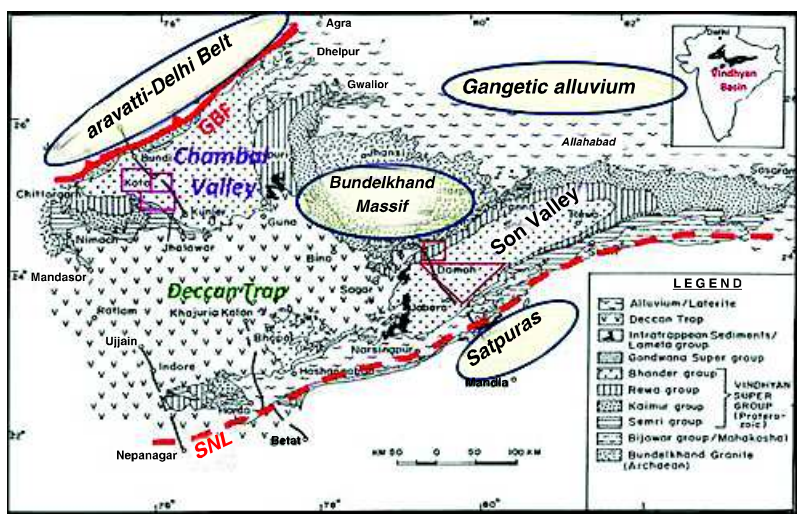

Fig. 13: Geological map of Vindhyan Basin (after ONGC) 


\section{Category-IV Basins}

Most of these Basins are less explored in comparison to the category I and II Basins and are located in logistically difficult terrains/environments with inherent geological complexities. Exploration ventures in these Basins are capital intensive with uncertain return. However, considering the huge potential of hydrocarbon resources, more aggressive exploration is required, which can make a significant impact on the national hydrocarbon portfolio in the long run.

Exploration was carried out since 1956 in diverse geographical and geological regions of Frontier Basins like Spiti-Zanskar and Karewa Basin, Deccan Syneclise, Pranhita-Godavari, Narmada, and SatpuraS. Rewa-DamodarBasins; however, the success so has been was elusive.

\section{Unconventional Hydrocarbons}

Apart from conventional hydrocarbon occurrences discussed above, there are other types of hydrocarbon resources. These are, Coal Bed Methane (CBM), Shale Gas, and Gas Hydrates (GH). India, keeping the increasing demand for hydrocarbons is formulating the policies for exploration and exploitation of these unconventional resources. Of these, CBM exploration initiated towards the end of the last century is in advanced stage and exploitation has started in some areas. Special focus is on gas hydrates $(\mathrm{GH})$ since preliminary investigation indicated good resource potential. India has already established the physical presence of GH in offshore deep water part of Krishna-Godavari, Mahanadi and Andaman areas. Exploration for shale oil shale \&gas are in initial stages.

\section{Coal Bed Methane}

The adsorbed methane in coal bed which was known to be the potential hazard in coal mining is now economically exploited through bore holes at depth rages of $500 \mathrm{~m}$ to $1000 \mathrm{~m}$. India has the fifth largest proven coal reserves in the world and thus holds significant prospects for exploration and exploitation of CBM. The prognosticated CBM resources in the country are about 92 TCF (2600 BCM) in 12 states of India, especially the eastern coal fields of Damodar-Koel valley and Son valley.

As an initiative to harness the CBM potential, GOI has awarded 33 CBM blocks and commercial production commenced from July, 2007.

\section{Gas Hydrates}

Methane gas hydrate in the seabed shallow sediments is a prolific source of gas containing both biogenic and thermogenic gas. In India, presence of gas hydrate has been established in deep offshore of KG, Mahanadi and Andaman areas (DGH, 2010). National Gas Hydrate Program of Government of India conducted the first expedition in 2006 and the second expedition of Gas Hydrates commenced in 2015. Intensive R\&D studies are being carried out to evolve technologies to produce gas from frozen sea-bed sediments and India is ranked third in this endeavour after USA and Japan.

\section{Shale Gas}

Shale gas and oil constitute an important unconventional source of hydrocarbons stored in organic rich, matured fine grained sedimentary rocks. Hydro fracturing is an essential operational activity to explore the unconventional hydrocarbons from the shale which is impervious in nature with permeability in nano scale. Meso-Neo Proterozoic source facies of Vindhyan Basin and Permian source facies of Gondwana Basins besides the conventional deeper source shales are the potential shale gas/oil resources. Six Indian sedimentary Basins viz., Cambay, KG, Cauvery, Assam-Arakan, Ganga Valley and Damodar Basin were identified for shale oil/gas exploration.

India embarked on an ambitious Shale oil and gas programme and exploration programme in 55 blocks has been initiated by NOC's.

\section{Technology Induction to Enhance Exploration Efforts}

Technology induction being an integral part of hydrocarbon exploration, following new technologies are implemented in Indian Sedimentary Basins

- $\quad$ Long Offset 2D seismic surveys for deeper imaging

- 3D-3C/4D Seismic Surveys

- Wide Azimuth surveys

- $\quad$ Onshore carpet 3D surveys

- Node based Wide angle refraction cum reflection profiling. 
- Broadband Surveys

- CSEM surveys and Microgravity data for delineation

- $\quad$ Bean PSDM processing

- Common Reflection Angle Migration processing

- Discreet Fracture Net work Analysis

- Permeability structure analysis and fluid replacement studies

\section{Summary}

Exploratory efforts by E\&P companies have discovered 7 producing Basins and converted about 11.18 BTOE out of the prognosticated resource of 28

\section{Abbreviations Used}

2D/3D/4D : Two-dimensional/three dimensional/four dimensional (time-lapsed)

3D-3C : Three dimension - Three component

BCM : $\quad$ Billion Cubic meters

BOPD : Barrels of oil per day

BTOE: Billion Tonnes Oil equivalent

CAAGR: Compounded Average Annual growth rate

CBM : $\quad$ Coalbed Methane

CRAM: Common Reflection Angle Migration

CSEM: Controlled Source Electro Magnetic

DFN : $\quad$ Discreet Fracture Net work.

DGH : Directorate General of Hydrocarbons

E\&P : $\quad$ Exploration and Production

EOB: Eastern OceanBasin

FRM : $\quad$ Fluid Replacement Model

GH : $\quad$ Gas Hydrates

GOI: Government of India

GSI: Geological Survey of India

HELP: Hydrocarbon Exploration Licensing Policy

HOEC: Hindustan Oil Exploration Company
BTOE. A growth of about $32 \%$ compared to base year of 2006 in Initial In-Place volume.

Exploratory efforts have brought down the unexplored sedimentary Basinal area to a mere $12 \%$ compared $50 \%$ as in 1995.

Continued exploratory efforts leveraging the new technologies are resulting in new discoveries from Category -I Basins and more commercial discoveries from Category-II Basins like Mahanadi and Kutch.

Challenges in term of exploring and exploiting the HP-HT and Ultra HP-HT reservoirs exists and India is gearing up to meet the challenges through induction of new technologies.

HPB: Heera-Panna-Bassein

HPHT: High Pressure-High Temperature

KG : Krishna-Godavari

LWD: Logging While drilling

MBPD: Million Barrels per day

MPD : $\quad$ Managed Pressure Drilling

MMSCD/MMSCMD: Million Metric Standard Cubic Meters Per Day

NANG: Non associated Natural Gas

NEC: $\quad$ Northern East Coast

NELP : New Exploration Licensing Policy

NOC : National oil Companies

OIL : Oil India Ltd.

ONGC : Oil and Natural Gas corporation Ltd

PSU : $\quad$ Public Sector Undertaking

PST: $\quad$ Passive Seismic tomography

RIL: $\quad$ Reliance Industries Limited

RSS: $\quad$ Rotary Steerable System

SBL : $\quad$ Sea bed logging

WAZ: Wide Angle Azimuth

WARRP: Wide angle Refraction cum Reflection profiling. 


\section{References}

Anirbid Sircar (2004) Hydrocarbon production from fractured basement formations Current Science 87 147-151

Bastia R (2007) Geologic setting and petroleum systems of India's east coast offshore Basins-concepts \& applications Technology Publications, Dehradun, p 1-124

Biswas S K (2009) The Upper Assam Inter-Orogenic Peripheral Foreland Basin - a Special type of Peripheral Foreland Basin in Northeast India - an Overview on TectonoSedimentary Evolution. Nat. Semi. On geodynamics Mizoram Univ \& Geol Soc Ind Souvenir 77-89

Biswas S K (2008a) PetroliferousBasins of India - Fifty years' history and perspective Mem Geol Soc India 66 159-202

Biswas S K (2008b) Geodynamics of Indian plate and evolution of Mesozoic-CenozoicBasins Mem Geol Soc India 74 247260

Biswas S K (2012) Status of Petroleum Exploration in India Proc Indian natn Sci Acad 78 September 2012 475-494

Biswas S K (1989) Hydrocarbon exploration in western offshore Basins of India Geol Surv India Spl Pub 24 184-194

Biswas S K (1982) Rift Basins in western margin of India with special reference to hydrocarbon prospect Bull Amer Assoc Petro Geol 66 1497-1513

Biswas S K (1987) Regional tectonic framework, structure and evolution of the western margin Basins of India Tectonophysics 135 307-327

Biswas S K (1995) Prospect of coal bed methane in India Indian Jour Petro Geol 4 1-23

Biswas S K (1998) Overview of sedimentary Basins of India and their hydrocarbon potential In: R N Tiwari (ed) Recent researches in sedimentary Basins - implications in the exploration of natural resources. Indian Petroleum Pub., Dehradun, p 1-25

Biswas S K (2002) Structure and tectonics of the Kutch Basin, Western India, with special reference to Earthquakes. $8^{\text {th }}$. IGC Foundation Lecture, Indian Geological Congress, Roorkee, p 1-21

Biswas S K (2003) Regional tectonic framework of PranhitaGodavari Basin India Jour Asian Earth Sci 21 543-552

Biswas S K (2005) A review of structure and tectonics of Kutch Basin, Western India, with special reference to earthquakes Curr Sci 88 1592-1600

Biswas S K and Singh N K (1988) Western continental margin of India and hydrocarbon prospects of deep sea Basin Proc $7^{\text {th }}$ Offshore SE-Asia Conf Singapore OTSC 88119, p 170181

Biswas S K, Bhasin A L and Ram J (1993) Classification of
Indian sedimentary Basins in the framework of plate tectonics Proc Second Seminar on PetroliferousBasins of India Indian Petroleum Pub Dehradun 1 1-46

Biswas S K, Rangaraju M K, Thomas J and Bhattacharya S K (1994) Cambay-Hazad (!) petroleum system in south Cambay Basin, India In Magoon L B and W G Dow (eds), The Petroleum System - from source to trap Mem Amer Assoc Petro Geol 60 615-624

Biswas S K (2012) Status of Petroleum Exploration in India Proc Indian Natn Sci Acad 78 September 2015, pp 475-494

Chandrasekhar N, Mane P H, Rajappan P (2015) Basement Hydrocarbon Exploration-Overview of Petroleum system, Multi-component seismic analysis, identification of fractures and status of Indian Basin Exploration, Geohorizons, July 2015, 36-44

Das Gupta A B and Biswas A K (2000) Geology of Assam Geol Soc India Pub 169p

Das Gupta U and Bulgauda S S (1994) An overview of the geology and hydrocarbon occurrences in the western part of Bikaner-Nagaur Basin Ind Jour Petrol Geol 1-17

DGH (2015) Hydrocarbon exploration and production activities, India, 2014-15. p. 14-17, 100-108,112-118, 152-153

DGH (2007) Petroleum exploration and production activities, India, 2006-07 p 82-83

DGH (2010) Petroleum exploration and production activities, India, 2009-10 73 107-113

Dhar P C and Bhattacharya S K (1993) Status of exploration in the Cambay Basin Proc. Second Seminar on PetroliferousBasins of India Indian Petroleum Publishers, Dehradun 2 1-32

Dolson John, Burley, Stuart D, Sunder V R, Kothari V, Naidu, Bodapati, Nicholas P, Paul Farrimond, Whitely, Taylor Andrew, Direen Nicholas and Anathakrishnan B (2015) The discovery of the Barmer Basin, Rajasthan,India, and its petroleum geology Amer Assoc Petro Geol 99 433-465

Fuloria R C (1993) Geology and hydrocarbon prospects of Mahanadi Basin, India Proc Second Seminar on PetroliferousBasins of India, Indian Petroleum Pub., Dehradun $1355-370$

Ganguly, Susnato (1993) Stratigraphy, sedimentation and hydrocarbon prospects of the Tertiary succession of Tripura and Cachar (Assam) Ind Jour Geol 65 145-180

Katz M B (1978) Sri Lanka in Gondwanaland and the evolution of the Indian Ocean Geol Mag 115 237-316

Indian Energy Outlook (2015) In World energy outlook Special Publication by International energy Agency

Powell C, Me A, Roots S R and Veevers J J (1988) Pre-break up 
continental extension in East Gondwanaland and the early opening of the eastern Indian Ocean Tectonophysics 155 261-283

Venkatarengan R and Ray D (1993) Geology and petroleum systems, Krishna-Godavari Basin.Proc.Second Seminar on Petroliferous Basins of India, Indian Petroleum Pub Dehradun 1 331-354

Wani M R and Kundu J (1995) Tectonostratigraphic Analysis in Cambay rift Basin, India: Leads for future exploration Proc PETROTECH conf Technology Trends in Petroleum Industry, New Delhi, 147-164

Kundu J and Wani M R (1992) Structural styles and tectonostrigraphic framework of Cambay rift Basin, Western India Ind Jour Petro Geol 1 181-202

Kundu J, Wani M R and Thakur R K (1993) Structural style in south Cambay rift and its control on post rift deltaic sedimentation Proc Second Seminar on Petroliferous Basins of India, Indian Petroleum Pub., Dehradun 2 79-96

Max M D and Lowrie A (1996) Oceanic methane hydrates: a “frontier" gas resource Jour Petro Geol 19 41-56

Mitra P, Mukherjee M K, Mathur B K, Bhandari S K, Qureshi S $M$ and Bahukhandi G C (1993) Exploration and hydrocarbon prospect in Jaisalmer Basin, Rajasthan Proc Second Seminar on Petroliferous Basins of India, Indian Petroleum Pub., Dehradun 2 235-284

Murty K N (1983) Geology and hydrocarbon prospects of Assam shelf - recent advance and present status.Petroliferous Basins of India, pt. I, Petroleum Asia Jour VI 1-14

Rai A, Chandrasekharam P and Misra V N (1998) Indian sedimentary Basins and their hydrocarbon potential In $\mathrm{R}$ $\mathrm{N}$ Tiwari (ed) Recent researches in sedimentary Basins implications in the exploration of natural resources. Indian Petroleum Pub., Dehradun, p 91-103
Rao G N (2001) Sedimentation, stratigraphy, and petroleum potential of Krishna-Godavari Basin, east coast of India Bull Amer Assoc Petro Geol 85 1623-1643

Raju D S N et al. (2008) Stratigraphy of India ONGC Bulletin 43 10-39

Rangaraju M K, Agarwal A and Prabhakar K N (1993) Tectonostratigraphy, structural styles, evolutionary model and hydrocarbon habitat, Cauvery and Palar Basins Proc Second Seminar on Petroliferous Basins of India Indian Petroleum Pub., Dehradun 1 371-388

Roy Sandip K and Das Sharma S (1993) Evolution of Andaman fore arc Basin and its hydrocarbon potential Proc Second Seminar on Petroliferous Basins of India Indian Petroleum Publishers, Dehradun 1 407-435

Shyam Chand and Subrhmanyam C (2001) Subsidence and isostasy along a sheared margin - Cauvery Basin, eastern continental margin Geoph Res Lett 28 2273-2276

Sinha A K, Yadav R K and Qureshi S M (1993) Status of exploration in south Shahgarh sub-basin of Jaisalmer Basin, Rajasthan Proc Second Seminar on Petroliferous Basins of India, Indian Petroleum Pub., Dehradun 2 285-334

Sudhakar R (1990) Scope of integrated exploration research in Krishna-Godavari, Cauvery and Andaman Basins Proc Conference on Integrated Exploration Research Achievements and Perspectives, Unpublished reports of ONGC and inputs from various formations. 